\title{
Transfer of chemical elements in vapor-gas streams at the dehydration of secondary sulfates
}

\author{
Svetlana Bortnikova ${ }^{1}$, Nataliya Yurkevich $^{1, *}$, Anna Devyatova ${ }^{1}$, Natalya Abrosimova ${ }^{1}$, \\ Olga Saeva ${ }^{1}$, Nikolay Cherny ${ }^{2}$, Nadezhda Palchik $^{3}$, Irina Danilenko ${ }^{3}$, Olga Shuvaeva ${ }^{4}$, and \\ Dmitry Troitskii ${ }^{4}$ \\ ${ }^{1}$ Trofimuk Institute of Petroleum Geology and Geophysics SB RAS, 630090, Ac. Koptyug av., 3, \\ Novosibirsk, Russia \\ ${ }^{2}$ LLC "Recycling", 650000, Kuznezky av., 33G, Kemerovo, Russia \\ ${ }^{3}$ Sobolev Institute of Geology and Mineralogy SB RAS, 630090, Ac. Koptyug av., 3, Novosibirsk, \\ Russia \\ ${ }^{4}$ Nikolaev Institute of Inorganic Chemistry SB RAS, 630090, Ac. Lavrentiev av. 3, Novosibirsk, \\ Russia
}

\begin{abstract}
The elemental composition of vapor-gas streams obtained during heating of secondary hydrous sulfates are presented. Samples of abundant sulfate intergrowth were collected at the Belovo waste heaps and heated at $60^{\circ} \mathrm{C}$ in experiments to collect condensates of the releasing vapor-gas streams. A wide spectrum of major and trace elements was determined in the condensate. Chemical elements can be absorbed by the water vapor and migrate with this phase during the dehydration of hydrous sulfates. To determine the mechanisms of migration and the sources of elements in vapor-gas streams, a study of the features of certain hydrous sulphates (antlerite, goslarite, starkeyite, gunningite, siderotile, sideronatrite) by stepwise heating up to $60^{\circ} \mathrm{C}$ was conducted. Alteration in the phase composition is controlled by powder X-ray diffractometry. It was determined, that antlerite and starkeite remain stable throughout the temperature range. The beginning of the separation of structural water in goslarite and siderotile occurs at $40^{\circ} \mathrm{C}$. Goslarite and sideronatrite at $40^{\circ} \mathrm{C}$ lost water molecules and transformed to gunningite and Na-jarosite, correspondingly. Structure of siderotile was loosened. The modes of occurrence of the chemical elements in sulfates and pore solution determine the concentrations of elements in the condensates.
\end{abstract}

\section{INTRODUCTION}

Metal-sulphate salts play an important role in the storage of acids and metals released during the weathering of mineralized rocks, coal deposits, metallic ore deposits, and mine wastes [1-3]. A large amount of work has been devoted to the study of sulphate minerals as an important link in the process of water-sulphide interactions. An investigation of the

* Corresponding author: YurkevichNV@ipgg.sbras.ru 
phase relationships and dehydration mechanisms of sulfate-mineral mixtures is important in determining how mine waste interacts with the local environment and in understanding the processes by which mine waste matures with time and reacts to changes in temperature and (or) humidity [4]. Recently, there has been increasing interest in the use of salt hydrates as thermochemical heat storage materials [5-6]. Another important direction in the research of secondary mineral dehydration is chemical element transport in the vapor streams [7-9]. The purpose of this work was to deter-mine the composition of the vapor-gas mixture separated from sulphate minerals during heating.

\section{STUDY AREA}

For the experiments, efflorescence crust samples were collected from the surface of the Belovo waste heaps (Belovo zinc processing plant, Russia). The mineralogy and internal structure of the Belovo waste heaps have been described in detail earlier [10-12, 7]. Approximately $20-25 \%$ of fine-grained coke breeze occur in the waste, which caused the burning of the dump for many years. Due to the intensive transformation of the slags under the influence of oxidizing agents, intensified by combustion, abundant efflorescences consisting of sulfates of $\mathrm{Fe}, \mathrm{Cu}$, and $\mathrm{Zn}$ were formed on the surface.

\section{METHODS}

\subsection{Field sampling}

During field work under hot, dry weather conditions, efflorescence samples were collected from the surface of the waste heaps (Fig. 1). A bulk sample consisting of an intergrowth of sulphates was collected from lens in clinker material for pore water squeezing and laboratory experiments. It was kept tightly packed in polyethylene bags. Individual sulphates were taken from incrustation on the lens boundary in sealed plastic containers.

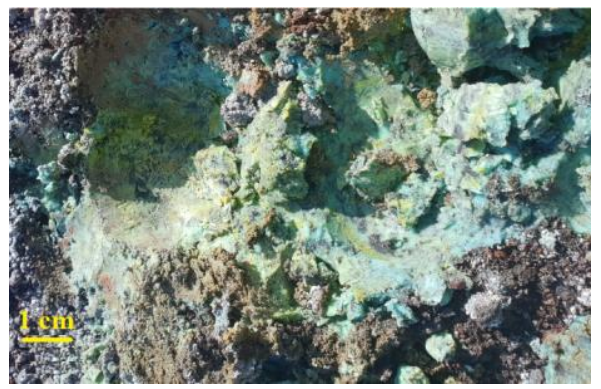

Fig. 1. Photo of secondary sulfates on heap surface.

\subsection{Laboratory analyses}

Pore solutions were squeezed from the $0.5 \mathrm{~L}$ of the bulk sample at a pressure of $100 \mathrm{kPa}$. To obtain condensates, $100 \mathrm{~g}$ of the bulk samples (before and after pore water squeezing) were placed in a heat-resistant beaker covered with a funnel that was connected to the bubbler inlet with a silicone hose. An air-gas mixture was pumped out of the ice-cooled bubbler through an exit port by means of a back-pressure pump (pumping speed $\sim 2.4$ 
$1 / \mathrm{min})$. The beaker was heated at a temperature of $60^{\circ} \mathrm{C}$ on the digital magnetic stirrer, and the condensate was collected in the bubbler.

For the study of individual sulphates, foreign sub-stances were removed from the samples of incrustation, and then the samples were sorted by hand-picking using a binocular microscope. Each sample was heated on a digital magnetic stirrer WiseStir MSH20D-Set (DAIHAN Scientific) at a temperature interval of 40 and $50^{\circ} \mathrm{C}$ for $1 \mathrm{~h}$ for each step under ambient air conditions. After each heating step, the samples were investigated using the ARL X'TRA X-ray diffractometer. Major and trace elements in condensates were determined using ICP-MS spectrometry (Agilent 8800 ICP-MS instrument (Japan) with Micro-Mist nebulizer).

\section{Results}

Pore solution squeezed from the bulk sample is highly mineralized acidic sulphate $\mathrm{Cu}-\mathrm{Zn}$ brine with TDS more than $300 \mathrm{~g} / \mathrm{L}$ and high concentrations of $\mathrm{Na}, \mathrm{Fe}$, and $\mathrm{Mg}$ and. Main trace elements are Mn and As (Table 1).

Samples consist of secondary hydrous sulphates of $\mathrm{Cu}, \mathrm{Zn}, \mathrm{Fe}$, and $\mathrm{Mg}$ (Table 2). Besides the main mineral-forming elements, sulphates contain admixtures of many metals and metalloids and thin mutual intergrowths due to complex composition of pore solutions from which they crystallized. The typical admixture in goslarite are $\mathrm{Cu}, \mathrm{Ni}, \mathrm{Fe}, \mathrm{Al}, \mathrm{K}, \mathrm{Ca}$, and $\mathrm{As}, \mathrm{Ba}, \mathrm{Co}$ are less common. Siderotile contains $\mathrm{Cu}, \mathrm{Zn}, \mathrm{Ni}, \mathrm{Co}, \mathrm{Mn}, \mathrm{Mg}$, and Ag. Starkeite is characterized by elevated concentrations of $\mathrm{Cu}, \mathrm{Zn}, \mathrm{Ni}, \mathrm{Fe}$, and $\mathrm{Mn}$.

Table 1. Element concentrations in the pore solution.

\begin{tabular}{|c|c|c|c|}
\hline Component & $\mathbf{g} / \mathbf{L}$ & Component & $\mathbf{~ m g / L}$ \\
\hline $\mathrm{SO}_{4}{ }^{2-}$ & 187 & $\mathrm{Si}$ & 29 \\
\hline $\mathrm{Ca}$ & 0.36 & $\mathrm{Cd}$ & 19 \\
\hline $\mathrm{Mg}$ & 8.6 & $\mathrm{Cr}$ & 16 \\
\hline $\mathrm{Na}$ & 15 & $\mathrm{Co}$ & 82 \\
\hline $\mathrm{K}$ & 0.023 & $\mathrm{As}$ & 870 \\
\hline $\mathrm{Fe}$ & 13 & $\mathrm{Sb}$ & 14 \\
\hline $\mathrm{Mn}$ & 0.97 & $\mathrm{Ba}$ & 0.46 \\
\hline $\mathrm{Al}$ & 1.2 & $\mathrm{Sr}$ & 1.8 \\
\hline $\mathrm{Cu}$ & 29 & $\mathrm{Ti}$ & 3.6 \\
\hline $\mathrm{Zn}$ & 47 & $\mathrm{~V}$ & 3.8 \\
\hline
\end{tabular}

Table 2. Mineral transformation of samples during heating procedure.

\begin{tabular}{|c|c|c|c|c|c|c|}
\hline \multirow{3}{*}{ Sample } & \multirow{3}{*}{ Mineral } & \multirow{3}{*}{ formula } & \multicolumn{4}{|c|}{ transformation at heating } \\
\hline & & & \multicolumn{2}{|r|}{$40^{\circ} \mathrm{C}$} & \multicolumn{2}{|c|}{$50^{\circ} \mathrm{C}$} \\
\hline & & & w.l. & $\begin{array}{c}\text { new-forming } \\
\text { mineral }\end{array}$ & w.l. & $\begin{array}{c}\text { new-forming } \\
\text { mineral }\end{array}$ \\
\hline BS-1 & antlerite & $\mathrm{Cu}_{3}\left(\mathrm{SO}_{4}\right)(\mathrm{OH})_{4}$ & 0.18 & n.a. & 1.4 & n.a. \\
\hline \multirow{3}{*}{ BS-2 } & goslarite & $\mathrm{Zn}\left(\mathrm{SO}_{4}\right) \times 7 \mathrm{H}_{2} \mathrm{O}$ & \multirow{3}{*}{23} & $\begin{array}{c}\text { gunningite } \\
\mathrm{ZnSO}_{4} \times \mathrm{H}_{2} \mathrm{O}\end{array}$ & \multirow{3}{*}{7.8} & n.a. \\
\hline & $\begin{array}{l}\text { sideronatri } \\
\text { te }\end{array}$ & $\begin{array}{c}\mathrm{Na}_{2} \mathrm{Fe}\left(\mathrm{SO}_{4}\right)_{2}(\mathrm{OH}) \times \\
3 \mathrm{H}_{2} \mathrm{O}\end{array}$ & & $\begin{array}{c}\text { Na-jarosite } \\
\mathrm{NaFe}_{3}\left(\mathrm{SO}_{4}\right)_{2}(\mathrm{OH})_{6}\end{array}$ & & n.a. \\
\hline & $\begin{array}{l}\text { cyano- } \\
\text { chrocite }\end{array}$ & $\mathrm{K}_{2} \mathrm{Cu}\left(\mathrm{SO}_{4}\right)_{2} \times 6 \mathrm{H}_{2} \mathrm{O}$ & & $\begin{array}{c}\text { poitevinite } \\
(\mathrm{Cu}, \mathrm{Fe}) \mathrm{SO}_{4} \times \mathrm{H}_{2} \mathrm{O}\end{array}$ & & $\begin{array}{c}\text { brochantite } \\
\mathrm{Cu}_{4}\left(\mathrm{SO}_{4}\right)(\mathrm{OH})_{6}\end{array}$ \\
\hline BS-5 & siderotile & $\mathrm{Fe}\left(\mathrm{SO}_{4}\right) \times 5 \mathrm{H}_{2} \mathrm{O}$ & 13 & $\begin{array}{c}\text { structure was } \\
\text { loosened }\end{array}$ & 8.9 & $\begin{array}{c}\text { parabutlerite } \\
\mathrm{Fe}\left(\mathrm{SO}_{4}\right) \times 2 \mathrm{H}_{2} \mathrm{O}\end{array}$ \\
\hline BS-5/1 & starkeyite & $\mathrm{MgSO}_{4} \times 4 \mathrm{H}_{2} \mathrm{O}$ & 3.8 & n.a. & 6.3 & n.a. \\
\hline BS-6 & gunningite & $\mathrm{ZnSO}_{4} \times \mathrm{H}_{2} \mathrm{O}$ & 13 & n.a. & 19 & n.a. \\
\hline
\end{tabular}


The first step of heating (at $40^{\circ} \mathrm{C}$ ) leads to transformation. Namely, goslarite, sideronatrite, and cyanochrocite lost molecules of structural water with noticeable weight loss, and transformed to gunningite, Na-jarosite, and poitevinite, correspondingly. Siderotile remained, but its structure was loosened. Antlerite, starkeite, and gunningite did not altered, loss of their weights occurred due to the separation of sorbed water. At the second heating step $\left(50^{\circ} \mathrm{C}\right)$ siderotile lost 3 water molecules and was transformed to parabutlerite. Brochantite was formed from poitevinite. Other minerals remained as they were after the first heating step. Thus, collected condensate from the dry sample is both from sorbed and structural water. Condensate from the wet sample contains also some part of the water from pore solution.

Condensates contain a wide range of elements both from wet (before pore water squeezing - BC-1) and dry (after squeezing - BC-2) samples (Table 3).

Table 3. Element concentrations in condensates, $\mathrm{Ca}-\mathrm{Sr}$ in $\mathrm{mg} / \mathrm{L} ; \mathrm{Al}-\mathrm{Li}$ in $\mu \mathrm{g} / \mathrm{L}$.

\begin{tabular}{|c|c|c|c|c|c|}
\hline & BC-1 & BC-2 & & BC-1 & BC-2 \\
\hline $\mathrm{Ca}$ & 1.8 & 1.1 & $\mathrm{Al}$ & 5.2 & 4.6 \\
\hline $\mathrm{Mg}$ & 0.39 & 0.16 & $\mathrm{Cd}$ & 1.6 & 3.0 \\
\hline $\mathrm{Na}$ & 0.25 & 0.18 & $\mathrm{Cr}$ & 0.19 & 1.9 \\
\hline $\mathrm{K}$ & 0.30 & 0.25 & $\mathrm{Co}$ & 0.58 & 0.50 \\
\hline $\mathrm{Fe}$ & 0.013 & $<0.005$ & $\mathrm{Ag}$ & 0.052 & 0.021 \\
\hline $\mathrm{Mn}$ & 0.034 & 0.034 & $\mathrm{As}$ & 10 & 7.9 \\
\hline $\mathrm{Si}$ & 0.45 & 0.38 & $\mathrm{Sb}$ & 0.092 & 0.025 \\
\hline $\mathrm{Cu}$ & 0.089 & 0.030 & $\mathrm{Rb}$ & 0.65 & 0.76 \\
\hline $\mathrm{Zn}$ & 0.11 & 0.023 & $\mathrm{Ti}$ & 0.31 & 0.29 \\
\hline $\mathrm{Ba}$ & 0.0077 & 0.0048 & $\mathrm{~V}$ & $<0.3$ & 0.74 \\
\hline $\mathrm{Sr}$ & 0.011 & 0.0072 & $\mathrm{Li}$ & 0.38 & 0.36 \\
\hline
\end{tabular}

Calcium is the major cation, and $\mathrm{Mg}, \mathrm{K}, \mathrm{Si}$, and $\mathrm{Na}$ are less abundant. Among metals, the highest concentrations are for $\mathrm{Zn}$ and $\mathrm{Cu}$ as mineral-forming elements. However, the concentration of $\mathrm{Fe}$ is much lower than we would expect. Low mobility of $\mathrm{Fe}$ in comparison with other metals was noted previously [8-9]. Trace elements such as $\mathrm{Ba}, \mathrm{Sr}$, $\mathrm{Al}$, As, and others are determined in condensates in measurable concentrations.

The observed features of the composition of the vapor phase were determined, apparently, by the crystalline structure of the minerals. The effect of leaching cations and admixture from minerals is known to occur when they interact with water. The cations then go into solution, being replaced by $\mathrm{H}^{+}$ions. It is not excluded that such a reaction occurs in the near-surface layer of the mineral when it is exposed to water sorbed on the surface of the grain. In this case, condensation of the formed vapors on less heated areas of the surface and structural defects are possible, since the sample is heated unevenly.

When hydrous sulphates are heated, dehydration of structure water is added to the sorbed water. The resulting water reacts with the surface of the solid phase. However, it is possible that cations can be extracted from the crystal lattice, being replaced by protons. This is evidenced by a high concentration of elements in condensates from $\mathrm{Cu}-$ and $\mathrm{Zn}$ sulphates.

Condensate from the wet sample is characterized by higher concentrations of all the elements, obviously due to double source: crystal structure (sulphate minerals) and pore solution. Although the excess concentrations of elements in condensates from the wet sample are not as large as one would expect, based on the high salinity of the pore solution. The concentration of $\mathrm{Cd}, \mathrm{Cr}, \mathrm{Rb}$, and $\mathrm{V}$ is higher in the condensate obtained from dry samples. High concentration of $\mathrm{SO}_{4}{ }^{2-}$ in pore solution $(187 \mathrm{~g} / \mathrm{L})$ determines formation of sulfate complexes of metals, which are characterized by inert behavior during separation of 
vapor phase. The water vapor phase transports elements in the form of aqua-ions, but complexed species (such as $\mathrm{MeSO}_{4(\mathrm{aq})}$ ) remain in the salt residue.

\section{CONCLUSION}

A wide range of chemical elements can migrate in a vapor-gas stream at low temperature heating of secondary hydrous sulfates $\left(60^{\circ} \mathrm{C}\right)$, which was determined by the analysis of condensates. Condensate from the wet sample contains higher element concentration due to the inflow of elements from pore solution and hydrous sulphates. Vapor from the dry sample consists of sorbed and structural water. The destruction of goslarite and sideronatrite with the separation of water occurs at $40^{\circ} \mathrm{C}$. Structural water is separated from these minerals, after which new minerals are formed (gunningite from goslarite and $\mathrm{Na}$ jarosite from sideronatrite). At $50^{\circ} \mathrm{C}$ siderotile lost 3 water molecules and was transformed to parabutlerite. Brochantite was formed from poitevinite. Antlerite and starkeite remain stable in the temperature range (up to $50^{\circ} \mathrm{C}$ ). Alterations in mineral structure and water release are proved by the loses of sample weight. With dehydration, cations and trace elements can be extracted from the crystal lattice, being replaced by protons.

The researches were financially supported by the RFBR (Grant № 17-05-00056).

\section{References}

1. .L. Jambor, D.K. Nordstrom, C.N. Alpers, Rev. Min. Geochem. 40, 303-350 (2000)

2. T.M. Valente, C.L. Gomes, Sci. Tot. Env. 407, 1135-1152 (2009)

3. T. Valente, J.A. Grande, M.L. De La Torre, M. Santisteban, J.C. Cerón, Appl. Geochem. 39, 11-25 (2013)

4. R.C. Peterson, J.M. Hammarstrom, R.R. Seal, Am. Min. 91, 261-269 (2006)

5. C. Ferchaud, Experimental study of salt hydrates for thermochemical seasonal heat storage. (Technical University Eindhoven, Eindhoven, 2016)

6. P.A.J. Donkers, L.C. Sögütoglu, H.P. Huinink, H.R. Fischer, O.C.G. Adan, Appl. En. 199, 45-68 (2017)

7. S. Bortnikova, V. Olenchenko, O. Gaskova, K. Chernii, A. Devyatova, D. Kucher, Appl. Geochem. 78, 105-115 (2017)

8. S. Bortnikova, N. Yurkevich, N. Abrosimova, A. Devyatova, A. Edelev, A. Makas, M. Troshkov, J. Geochem. Exp. 186, 256-269 (2018)

9. S. Bortnikova, N. Yurkevich, A. Devyatova, O. Saeva, O. Shuvaeva, A. Makas, M. Troshkov, N. Abrosimova, M. Kirillov, T. Korneeva, T. Kremleva, Sci. Tot. Env. 647, 411-419 (2019)

10. N. Sidenko, R.Giere, S. Bortnikova, F. Cottard, N. Palchik, J. Geochem. Exp. 74, 109125 (2001)

11. S. Bortnikova, Yu. Manstein, O. Saeva, N. Yurkevich, O. Gaskova, E. Bessonova, R. Romanov, N. Ermolaeva, V. Chernuhin, A. Reutsky, Water Security in the Mediterranean Region (Springer, Netherlands, 2011).

12. O.L. Gas'kova, S.B. Bortnikova, Geochem. Intern. 45, 409 (2007) 